\title{
Correction to: Low-chloride- versus high- chloride-containing hypertonic solution for the treatment of subarachnoid hemorrhage-related complications: The ACETatE (A low ChloriE hyperTonic solution for brain Edema) randomized trial
}

Ofer Sadan ${ }^{1 *}$, Kai Singbartl ${ }^{2}$, Jacqueline Kraft ${ }^{1}$, Joao McONeil Plancher ${ }^{1}$, Alexander C. M. Greven ${ }^{3}$, Prem Kandiah', Cederic Pimentel ${ }^{1}$, C. L. Hall', Alexander Papangelou ${ }^{4}$, William H. Asbury ${ }^{5}$, John J. Hanfelt ${ }^{6}$ and Owen Samuels ${ }^{1}$

Correction to: J Intensive Care 8, 32 (2020)

https://doi.org/10.1186/s40560-020-00449-0

Following the publication of the original article [1], it was noted that Fig. 3b had an erroneous graph. The correct Fig. 3 has been included in this correction. The authors apologize for this error.

\section{Author details}

'Department of Neurology and Neurosurgery, Division of Neurocritical Care, Emory University Hospital and Emory University School of Medicine, 1364 Clifton Rd. NE, Atlanta, GA 30322, USA. ${ }^{2}$ Department of Critical Care Medicine, Mayo Clinic, 5777 E Mayo Blvd, Phoenix, AZ 85054, USA. ${ }^{3}$ School of Medicine, Emory University, 1364 Clifton Rd. NE, Atlanta, GA 30322, USA.

${ }^{4}$ Department of Anesthesiology, Emory University Hospital and Emory University School of Medicine, 1364 Clifton Rd. NE, Atlanta, GA 30322, USA. ${ }^{5}$ Department of Pharmacy, Emory University Hospital, 1364 Clifton Rd. NE, Atlanta, GA 30322, USA. 'Department of Biostatistics and Bioinformatics, Emory University, 1364 Clifton Rd. NE, Atlanta, GA 30322, USA.
Published online: 01 September 2020

\section{Reference}

1. Sadan $\mathrm{O}$, et al. Low-chloride- versus high-chloride-containing hypertonic solution for the treatment of subarachnoid hemorrhage-related complications: The ACETatE (A low ChloriE hyperTonic solution for brain Edema) randomized trial. J Intensive Care. 2020;8:32. https://doi.org/10. 1186/s40560-020-00449-0.

The original article can be found online at https://doi.org/10.1186/s40560020-00449-0

*Correspondence: ofer.sadan@gmail.com

'Department of Neurology and Neurosurgery, Division of Neurocritical Care, Emory University Hospital and Emory University School of Medicine, 1364 Clifton Rd. NE, Atlanta, GA 30322, USA

Full list of author information is available at the end of the article

(c) The Author(s). 2020 Open Access This article is licensed under a Creative Commons Attribution 4.0 International License, which permits use, sharing, adaptation, distribution and reproduction in any medium or format, as long as you give appropriate credit to the original author(s) and the source, provide a link to the Creative Commons licence, and indicate if changes were made. The images or other third party material in this article are included in the article's Creative Commons licence, unless indicated otherwise in a credit line to the material. If material is not included in the article's Creative Commons licence and your intended use is not permitted by statutory regulation or exceeds the permitted use, you will need to obtain permission directly from the copyright holder. To view a copy of this licence, visit http://creativecommons.org/licenses/by/4.0/ The Creative Commons Public Domain Dedication waiver (http://creativecommons.org/publicdomain/zero/1.0/) applies to the data made available in this article, unless otherwise stated in a credit line to the data. 


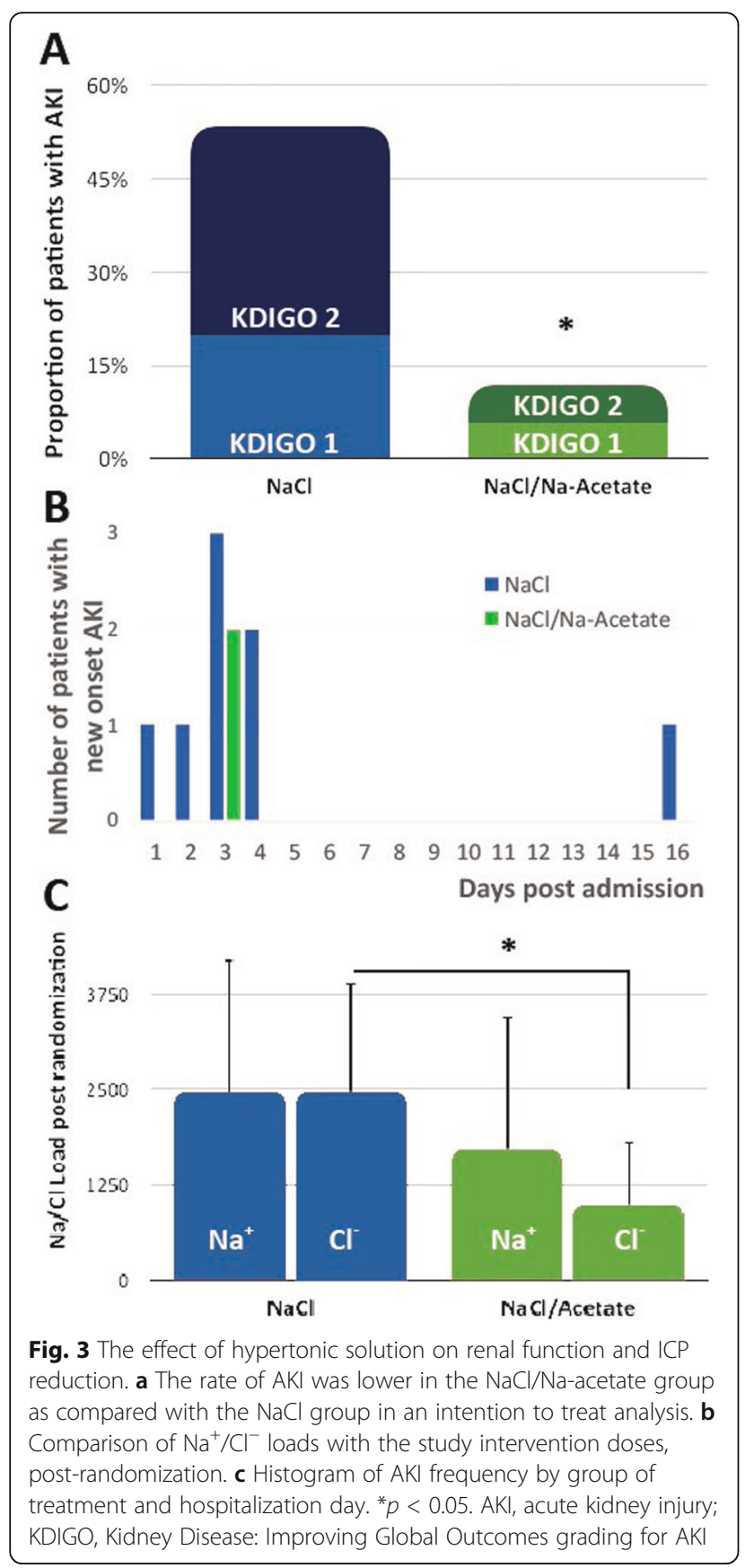

